\title{
透析液希釈水処理による血液透析患者の貧血改善
}

\author{
出井秀勇矢野栄二* 大坪公子** \\ 杤南クリニック 帝京大学公衆衛生* 三軒茶屋病院** \\ (昭和 60 年 5 月 13 日受付)
}

key words：血液透析，貧血，アスコルビン酸，軟水化・活性炭滤過処理，残留塩素

〈要旨〉

血液透析において透析液原液の希釈に使用する水道水には, 次亜塩素酸が含まれており, 透析患者の合併症の $1 つ$ の賓血の原因となっていると考えられている，そこで，透析液処理により賓血が改善するか否かを検討した。

透析液処理は，1）透析液原液 $10 \mathrm{l}$ にアスコルビン酸を $5 \mathrm{~g}$ の割合で添加し水道水を希釈水として作成，2）透 析液原液を軟水・活性炭濾過処理した水道水で希釈して作成, の 2 種の方法によった，貧血改善の指標としては，人 マトクリット $(\mathrm{Ht})$ 值の変化を観察した. 変化を追うにあたっては, 季節変動を考慮してなるべく年間の同時期を選 んで比較し, 尿素窒素 (BUN), クレアチニン, 総蛋白 (TP) 值についても検討を行った。 また, 残留塩素量を測定し 透析液処理による変化を比較した。

対象は, 昭和 56 年 11 月より昭和 59 年 9 月まで継続して透析療法を受けている男性 12 名, 女性 8 名の計 20 名. 年 齢は, 昭和 56 年 11 月の時点で男性 28 62 歳 (平均 42.6 歳), 女性 29 54 歳 (平均 41.1 歳). 透析導入後の経験期 間は, 男性 $0 \sim 88$ 力月 (平均 30.7 力月), 女性 $4 \sim 119$ 力月 (平均 53.9 力月) である. 未処理の透析液を使用する透 析に比べて，1），2）の処理を行う透析において Ht 值は有意 $(P<0.05)$ に上昇し，おのおのの処理を比較した場 合, 2 ) の透析で透析経験年数 3 年未満光して女性の患者に Ht 值の顕著な上昇を認めた。 BUN, クレアチニン, TP 值は $\mathrm{Ht}$ 值の変化とは関係せず, 尿毒素や栄養状態改善による $\mathrm{Ht}$ 值の変化ではないことを示した，残留塩素量を測 定すると, 水道水では $0.5 \pm 0.1 \mathrm{ppm}$, 未処理の透析液では $0.3 \pm 0.1 \mathrm{ppm}$ であったが, 1), 2 ) の処理透析液では 検出限界以下であった. 以上のことから，1 ，，2）の処理透析液を使用することにより貧血が改善され，并のうちで も，2）の軟水・活性炭濾過処理透析液の使用が特に賓血改善に有効であると考えられた。 またこれらの処理で, 溶 血の原因と考えられている残留塩素が除去されることも確認された.

\section{The effect of water treatment on anemia in hemodialysis patients}

Hideo Idei, Eiji, Yano, M.D*., and Kimiko Otsubo, M.D.**

Tochinan Clinic ; Department of Public Health, Teikyo University School of Medicine* ; Sangenjaya Hospital**

In hemodialysis therapy, hypochlorous acid contained in dialysate has been reported to be a cause of anemia, a frequent complication in uremic patients. Hypochlorous acid in dialysate can be removed by treating tap water used for diluting the dialysate condensate. In this study, the effect of water pretreatment on the anemia of 20 patients was investigated. The following methods of water treatment were introduced at separate periods :

1) $5 \mathrm{~g}$ of ascorbate was added to every $10 l$ of tap water or 2) tap water was treated with ion exchange resins followed by charcoal filtration. Residual chloride in the water before and after the water treatments was also assayed. As a result, the three month average hematocrit improved in 18 out of 20 patients after treatment 1 ), and all the patient showed improvement after treatment 2). This improvement in hematocrit was in accord with the decrease of hypochrolous acid. Women and those having less than three years' experience of dialysis therapy showed more prominent changes in hematocrit. Other factors such as seasonal variation, nutritional condition of the patients, and general status of the dialysis therapy were not likely to explain the improvement, as they were

出井秀勇 栃南クリニック

テ323 小山市駅東通り 1-21-21（0285-23-2159） 
already controlled in the study or not associated with the improvement. Thus, the two types of water treatment were shown to be effective to improve the anemia in hemodialysis patients, and hypochlorous acid was removed by these treatments.

\section{緒言・目的}

慢性腎不全による透析患者において貧血は，かなり高 頻度に認められる合併症である。その原因としては，造 血障害, 溶血六進, 出血, 透析による失血, その他の要 因が挙げられている11. そのうち溶血については, Kjel一 strand らが透析液希釈水道水の殺菌に用いられるクロ ラミンの影響を指摘し ${ }^{2)}$ ，川口はわが国においては次亜 塩素酸による溶血が考えられることを明らかにしてい $3^{3)}$. 近年クロラミン対策として, アスコルビン酸添加が 行われることがある1). 一方, 電解質改善の目的で軟水化 や活性炭濾過などの水の前処理が行われている。われわ れはこれらの方法が，水道水中に含まれる次亜塩素酸に よると思われる溶血六進を抑制し透析患者の貧血改善に 効果があるのではないかと考光，1）透析液原液へのア スコルビン酸の添加，2）水道水を軟水化抒よび活性炭 濾過処理し透析液原液の希釈水として使用，という 2 種 類の透析液処理を行い, それらに伴うへマトクリット值 の変化を観察した。また，水道水中の次亜塩素酸の指標 として残留塩素量を測定し, 比較検討した。

\section{対象・方法}

対象は, 当施設において昭和 56 年 11 月より継続して, 週 2 回ないし 3 回の透析療法を受けている糸球体腎炎を 原疾患とする腎不全患者のうち，後述するII・IV期に輸 血を行わなかった者で男性 12 名, 女性 8 名の計 20 名で ある。なお，I・III期に輸血を行った者は，図 2 のグラ フ中に記号で示す。年齢は昭和 56 年 11 月の時点で, 男

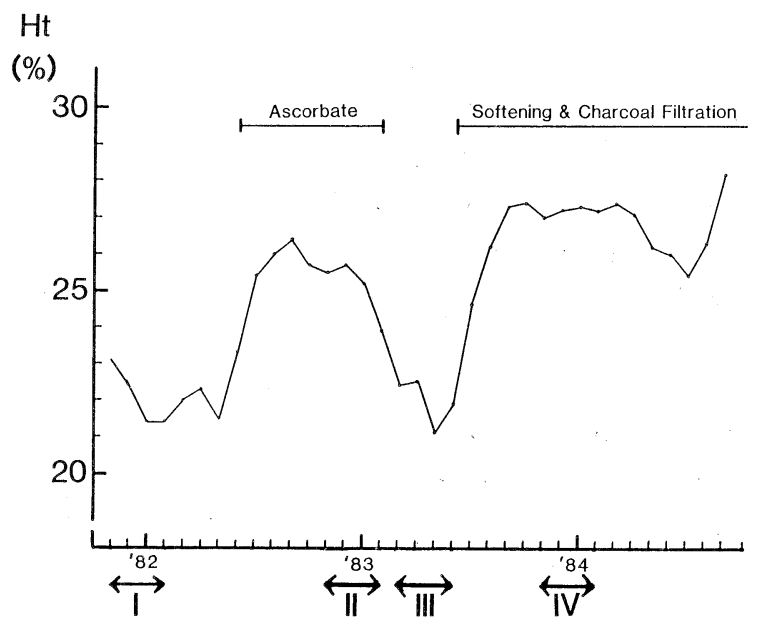

図 1 月別平均へマトクリット值
性は 28〜62 歳(平均 42.6 歳), 女性は 29〜 54 歳（平均 41.1 歳). 透析導入後の経験期間は, 男性 $0 \sim 88$ 力月 (平 均 30.7 力月), 女性 $4 \sim 119$ 力月 (平均 53.9 力月) であっ た.

透析液の処理方法は，時期を追って以下のように区別 される。 I 期：(昭和 56 年 11 月より 57 年 6 月 6 日まで) 未処理の水道水を希积水として使用。II期：(昭和 57 年 6 月 7 日より 58 年 1 月 24 日まで）透析液原液 $10 l$ にア スコルビン酸 $5 \mathrm{~g}$ を添加し(理論末端濃度 $14.3 \mathrm{mg} / l$ ), 水 道水を希釈液として使用。 III期：(昭和 58 年 1 月 25 日 より 58 年 5 月 29 日まで） I 期と同様未処理水道水を使 用. IV 期：（昭和 58 年 5 月 30 日より現在まで）水道水 を軟水化処理および活性炭濾過処理して希釈水として使 用。なお本研究では 59 年 9 月まで観察した結果を用いて いる. 軟水化処理は, 丸山製作所の全自動軟水器 MK-18 を使用し，再生は食塩により毎日行った。活性炭滤過処 理は, 全自動活性炭濾過器 TST-40C を使用し, 水道水 により再生を毎日行った。透析液は軟水化処理を行う IV 期開始に当って, 低 $\mathrm{Ca}$ 透析液 $(\mathrm{Ca}$ 值 $2.5 \mathrm{mg} / \mathrm{d} l)$ 加ら 高 $\mathrm{Ca}$ 透析液 $(3.5 \mathrm{mg} / \mathrm{d} l)$ に変更した.

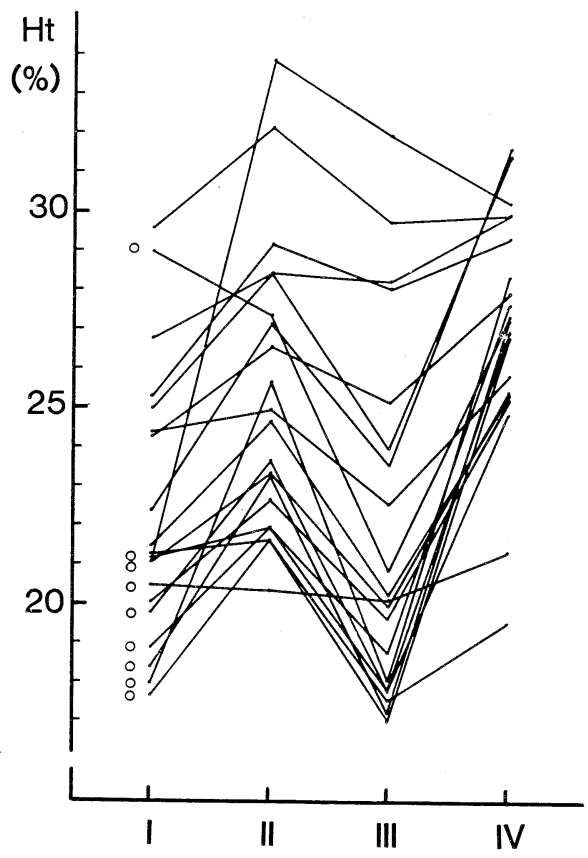

図 2 各期個人別平均へマトクリット值（○印は I また はIIIに輸血を受けた者） 
ヘマトクリットの測定は週 1 回，透析間隔の最もあい た日の透析前に測定し， 1 力月間の 4 ないし 5 回の測定 值を平均した。 月別平均值はこれを全員について平均し

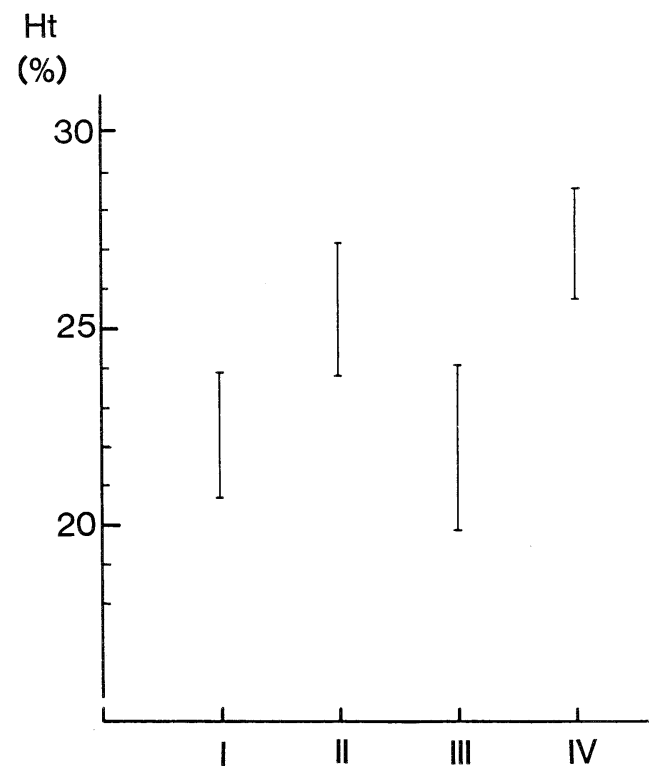

図 3 各期別平均へマトクリット值の $90 \%$ 信頼区間

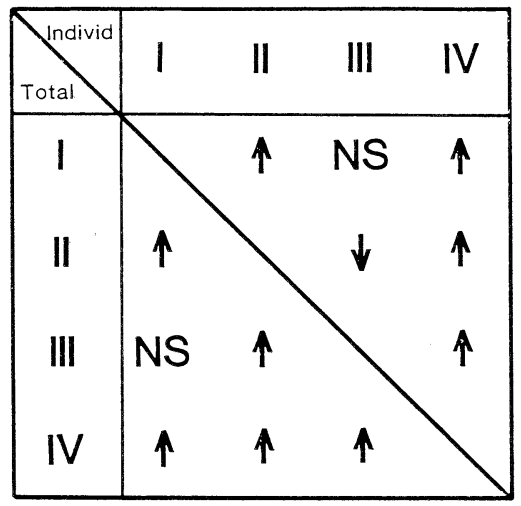

図4 個人別と全対象者の各期別平均へマトクリット值 の有意差検定（个または $\uparrow \mathrm{p}<0.05, \mathrm{NS}$ : 統計的 有意差なし）

\begin{tabular}{c|c|c|c|c|c}
\hline & $\begin{array}{c}\text { BUN } \\
(\mathrm{mg} / \mathrm{d} l)\end{array}$ & $\begin{array}{c}\text { creatinine } \\
(\mathrm{mg} / \mathrm{d} l)\end{array}$ & $\begin{array}{c}\mathrm{TP} \\
(\mathrm{g} / \mathrm{d} l)\end{array}$ & $\begin{array}{c}\mathrm{Hb} \\
(\mathrm{g} / \mathrm{d} l)\end{array}$ & $\begin{array}{c}\mathrm{RBC} \\
\left(\times 10^{4} \mathrm{~mm}^{3}\right)\end{array}$ \\
\hline I & $76.2-87.2$ & $12.8-14.9$ & $6.8-7.1$ & $6.9-8.0$ & $220-264$ \\
II & $69.1-77.5$ & $12.6-14.5$ & $7.2-7.6$ & $7.9-9.0$ & $263-307$ \\
III & $72.4-80.4$ & $12.6-14.5$ & $7.2-7.5$ & $6.5-7.7$ & $193-241$ \\
IV & $79.2-90.4$ & $13.2-15.2$ & $6.6-6.9$ & $8.2-9.2$ & $276-331$ \\
\hline
\end{tabular}

表 1 その他の検查值の各期別平均值の $90 \%$ 信頼区間
たものである。また前述各期のうち，昭和 56 年 11 月か ら 57 年 1 月, 昭和 57 年 11 月から 58 年 1 月, 昭和 58 年 3 月から 5 月, 昭和 58 年 11 月から 59 年 1 月の各 3 力月 間の全へマクリット值の平均を各期別の個人值とし，さ らに全対象者の平均值も期別に求め検定を行った。同様 の方法によって尿素窒素 (BUN), クレアチニン, 総蛋白 (TP) の值も検討し, ヘマトクリットの変化と比較した。 さらに他の貧血の指標としてへモグロビン，および赤血 球数の期別平均值を求めたが，検査頻度が期により異な るため参考值に留めた. 有意差の検定は各個人について の対応のある場合の $\mathrm{t}$ 検定を主に行ったが, 参考までに, 群全体の平均值の差の検定も一部示した。

残留塩素量の測定は，日本フィーダー工業のウォー ターテスターを使用し, 後述する各場所での試験水にオ ルトトリジン試薬を加え発色した測定水を濃度標準液と 比色した。測定した試験水は，1）水道水，2）活性炭 濾過処理水，3)水道水を希釈水として作成した透析液, 4) アスコルビン酸添加透析液原液を水道水で希釈して 作成した透析液，5）軟水化活性炭吸着処理水を希釈水 として作成した透析液の 5 種であり,それぞれ 24 回の測 定を行い平均值と標準偏差を求めた。検出限界は, 0.1 ppmである。

\section{結果}

昭和 56 年 11 月より 59 年 10 月までのへマトクリット 值の全員の月別平均を図 1 に示し, 各期個人別の平均值 を図 2 に示す.アスコルビン酸の添加処理によってへマ トクリット值は 20 人中 18 人において上昇し, アスコル ビン酸を中止すると再びへマトクリット值は下降した。 また，軟水化・活性炭濾過処理によってへマトクリット 值は全員上昇した。これを期別の平均值でみると図 3 に 示すように各期のへマトクリット值の $90 \%$ 信頼区間は

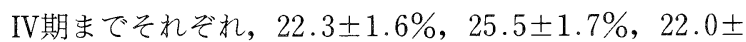
$2.1 \% ， 27.2 \pm 1.4 \%$ ある。へマトクリットの各期別の 平均值の差の検定を各期における個人別および全対象者 にわけて行った結果は図 4 に示す。以上の図と表から明 らかなようにへマトクリット值は，I期からII期にかけ て有意 $(\mathrm{p}<0.05)$ に上昇し，II期からIII期にかけて有意 $(\mathrm{p}<0.05)$ に下降，III期からIV期にかけて有意 $(\mathrm{p}<0.05)$ に上昇した。また，I 期とIII期では変らず，II期とIV期 では，個人別に比べると有意 $(\mathrm{p}<0.05)$ に上昇した。

$\mathrm{BUN}$ ，クレアチニン，TP およびへモグロビン，赤血 球数のそれぞれの期別平均値の $90 \%$ 信頼区間を表 1 に 示す. BUN および TP の各期における平均值は, へマ トクリットの各期に打ける変化とは関係なく変化し，ク レアチニンは，各期を通して変化しなかった。またへモ グロビン，赤血球数期別の変動はへマトクリット值とほ 


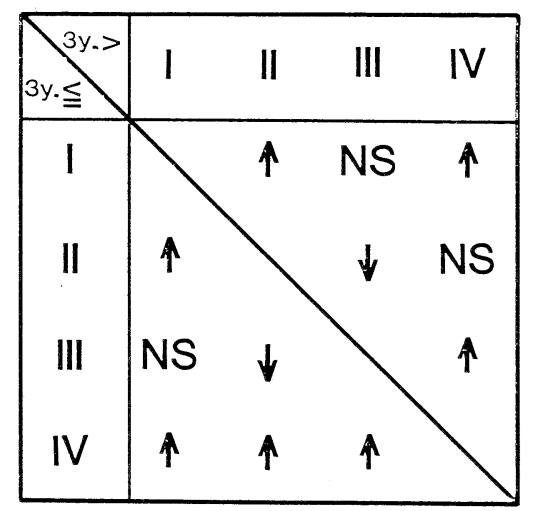

図 5 透析経験年数別（ 3 年未満と 3 年以上）の各期別 平均へマトクリック値の有意差検定（个または $\mathrm{p}<0.05, \mathrm{NS}$ ：統計的有意差なし）

\begin{tabular}{l|c}
\hline \multicolumn{1}{c|}{ Point of water collection } & $\begin{array}{r}\text { residual chloride } \\
(\mathrm{ppm})\end{array}$ \\
\hline $\begin{array}{l}\text { Tap water } \\
\text { Water after charcoal filtration }\end{array}$ & $0.5 \pm 0.1$ \\
Dialysate diluted with tap water & $0.3 \pm 0.1$ \\
$\begin{array}{l}\text { Ascorbate added dialysate diluted } \\
\text { with tap water (Phase II) }\end{array}$ & $\mathrm{ND}$ \\
$\begin{array}{l}\text { Dialysate diluted with softening \& } \\
\text { charcoal filtration water (Phase IV) }\end{array}$ & $\mathrm{ND}$ \\
\hline
\end{tabular}

表 2 各種処理による残留塩素量 (ND：検出限界以下)

ぼ同様の傾向を示した。

全対象者を透析経験年数 3 年末満と 3 年以上，また男 性と女性に分類してへマトクリットの各期別平均值の差 の検定を行った結果を図 5 , 図 6 に示す。希釈水処理に より, 透析経験年数 3 年未満の患者そして女性の患者に おいて貧血の改善が顥著であった.

残留塩素量の測定結果を表 2 に示す。透析液作成に当 り行った前処理により, 残留塩素量は検出限界の 0.1 $\mathrm{ppm}$ 未満に減少した。ここで未処理の水道水を希釈水と して作成した透析液 3）の残留塩素量が減少しているの は, 試験水の採取が末端コンソール寄りであるため, 恒 温層によるヒーティングや循環ポンプによる陰圧により 気泡化したためと思わ机る ${ }^{4)}$.

\section{考察}

慢性腎不全による透析患者の合併症の 1 つである貧血 は，高頻度に認められ，種々の原因が挙げられている。 その対策として, ビタミン剤, 鉄剤, 男性ホルモン剂等 の薬物投与, 消化器潰瘍, 痔核等よりの出血の対策, 透 析による残血や血液検査のための採血量を減らす工夫等 さまざまな処置が行われている。しかし，われわれの施

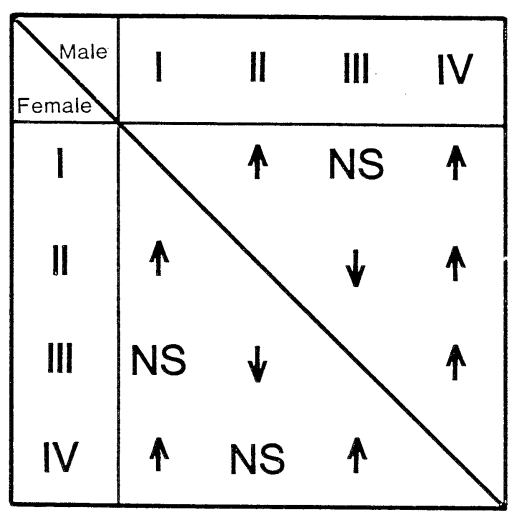

図 6 男女別の各期別平均へマトクリット值の有意差検 定（个または $\downarrow$ p $<0.05, \mathrm{NS}$ ：統計的有意差なし）

設ではこれらの方法では貧血改善効果の得られた例は少 なくむしろ輸血量が増加していた。

今回のわれわれの研究は, 貧血の原因の 1 つに水道水 中に含まれる次亜塩素酸が溶血を六進するとの報告 ${ }^{3} に$ 着目し, また, 次亜塩素酸は, 脱イオン, 蒸留, 煮沸, 活性炭濾過, 紫外線照射, アスコルビン酸の還元作用に よって除去することが可能であるとの報告 ${ }^{2}$ に基づくも のである.へマトクリット值を貧血の指標として経過観 察の結果, 水道水を直接希釈水として使用する透析 I 期 に比べて, アスコルビン酸添加のII期, 軟水・活性炭滤 過処理のIV期で有意にへマトクリット值は上昇し，I 期 と同条件透析のIII期では，I 期と同様低值を示した。そ して残留塩素量は, アスコルビン酸添加に打いても軟水 化処理を行うことによっても, 検出限界以下に減少する ことが確認された。すなおちアスコルビン酸添加透析液 原液使用や軟水化・活性炭濾過処理希釈水使用透析は透 析患者の貧血を改善し次冓塩素酸を除去することが示唆 された。

長期透析患者の貧血状態はここで検討している透析液 中の次亜塩素酸によると思われる溶血の他に季節変動, 患者の栄養状態や, 透析による血液浄化の程度の影響を うける。季節変動については，I，II期とIV期は年間の 同季節であり，その影響は無視することができる。また 患者の栄養状態や, 透析による血液浄化の程度の指標と しては TP と BUN・クレアチニンをとりあげ各期で比 較した. BUN 值および TP 值は各時期によって若干の 変化があるもののへマトクリット值の変化と一致せず, クレアチニン值は各時期を通じてほとんど一定で, 本集 団に打けるへマトクリット值の変化は栄養状態や尿毒素 によるものでもないといえよう。

また，薬剤の投与においては，I期開始の時点で，鉄 
剂投与者は, 20 名中 8 名であったが, IV 期終了時点では, 5 名に減少. 男性ホルモン郕も同じく, 6 名から 5 名に 減少し，鉄剤や男性ホルモン剂によって貧血が改善され たとは考えられない.

2 種の異なった処理を行ったII期とIV期を比較してみ ると, 個人別平均值は有意にIV期が高く, 図 5 , 図 6 に 示す分類別に分けて行った検定結果では, 透析経験年数 3 年未満抢よび女性の患者において有意にIV期が高い. このことの原因は不明であるが, II 期がアスコルビン酸 の還元作用による次亜塩素酸やクロラミンの中和のみで あるのに対し, IV期の活性炭濾過処理は, 次亜塩素酸以 外にも有機物を除去できることが関与していると考えら れる。一般に, 微量有機物の中には溶血作用等, 赤血球 寿命に影響を与えるものが存在し，その作用は特に，透 析経験年数が短い患者や赤血球膜抵抗の弱い傾向のある 女性 ${ }^{5)}$ の患者において強く現れる可能性がある。その結 果，II期とIV期に有意差が表われたと思われる。

以上のことにより透析液へのアスコルビン酸の添加や
水道水の軟水化扔よび活性炭濾過処理は, 残留塩素や有 害有機物等を除去し, 貧血の改善に有効であると考えら れた。

\section{文献}

1)太田和夫：透析療法とその周辺知識. p. 201-205, 1980, 南江堂, 東京.

2) Kjelstrand, C. M., Eaton, J. W., Yawata, Y., Swofford, H., Kolipn, C. F., Buselmeier, J., Hartizsch, B., Jacob, H. S. : Hemolysis in Dialized Patients caused by Chloramines. Nephron, $13: 427-433$, 1974.

3）川口俊介：慢性透析患者の溶血性貧血に関する研 究。日腎誌，XX I，6：567-583,1979.

4）化学実験ハンドブック編集委員会 : 化学実験ハンド ブック， p. 216,1974 , 技報堂.

5）川越裕也：CPC (Coil planet Centrifuge) 法, 日本 臨床，37 (夏季増刊号)：2250-2253,1979. 